\title{
PUBLIC POLICIES IN BRAZIL: systematic literature review
}

POLÍTICAS PÚBLICAS NO BRASIL: revisão sistemática da literatura POLIITICAS PÚBLICAS EN BRASIL: revisión sistemática de la literatura

\section{Airton Cardoso Cançado}

Doctorate in Administration from Universidade Federal de Lavras (UFLA). Adjunct Professor at Universidade Federal do Tocantins (UFT). airtoncardoso@yahoo.com.br.

0000-0003-4698-1804

\section{Fabiane Santos Barros}

Professional master's degree in Public Policy Management at Universidade Federal do Tocantins (UFT), in progress. fabianesantosbarros@gmail.com.

\section{0-0001-9496-8132}

\section{Fernando Santos Barros}

Professional Master's in in Public Administration PROFIAP na Universidade Federal do Tocantins (UFT). contnando@mail.uft.edu.br.

\section{0-0003-4051-6573}

Mailing address: Universidade Federal do Tocantins, Programa de Pós-Graduação em Desenvolvimento Regional. Av NS 15 ALC NO 14, Bloco 3, sala 33, Campus Universitário. 77001090 - Palmas, TO - Brasil
Received: 10.12 .2020

Accepted: 11.20 .2020

Published: 01.01.2021.

\begin{abstract}
:
This study aimed to analyze the evolution of public policies in the academic publications in Brazil from 2010 to 2019, from the perspective of their development, performances of the actors and social movements and the development of the public policy cycle phases. Thirty relevant studies were considered and in accordance with an issue addressed. An analysis enabled the division of articles into thematic axes, to presents the results and discussion about public policies in Brazil, actors and social movements and the public policy cycle. A recent analysis of public policies in Brazil can be considered, but with great advances after new federal constitution.

KEYWORDS Public Management; Public Policies; Public Policy Cycle.
\end{abstract}

\section{Introduction}

With the expansion of democracy, the function of the State was the welfare of society, to promote this, it uses public policies. Understanding the meaning of the term public policies is the first step to understanding the importance of this instrument to society. There are several definitions for this term, but a central idea among them is that the most important agent in the process of producing public policies is the government, for Smith and Larimer (2009), public policies concerns the process of making choices and what makes them public, and these choices are based on the coercive powers of the State.

For this research, the concept of public policies described by Secchi, Coelho and Pires (2019) was used, which is a guideline to solve a problem understood as collectively public, it has two fundamental elements, public intentionality and response to a public issue, this is considered the difference between the current state and what can be done to reach an ideal situation, for it to be public, it is necessary to have implications for a quantity or quality of people (Secchi, Coelho \& Pires, 2019). 
Public policies are materialized through programs, guidelines, projects, decrees, among others, seeking to meet the common demands of society, in a "public" way to ensure wide access.

Based on the importance of public policies for the development of the state and the well-being of society, this study aims to analyze the evolution of public policies in Brazil from 2010 to 2019, from the perspective of its development, the involvement of actors and social movements and the development of the public policies cycle phases.

The article is structured in four sections: after this introduction, the second section discusses methodological aspects; the third presents the thematic axes, from the qualitative analysis of the articles, finally, the fourth, presents a synthesis of the main findings of the study in the final considerations.

\section{Methodological Aspects}

In order to enable the development of this study, a systematic review of qualitative nature was chosen. The systematic review is a delineation of evidence originated in primary studies to answer a specific research question, for that, a comprehensive, impartial and reproducible literature review process is used, which locates, evaluates and synthesizes previous studies (Bork, 2005; BRASIL, 2012).

This type of research is a way of grouping knowledge on a given subject, facilitating the work of researchers. It is required an extensive effort of classifying and finding works that are relevant (Kitchenham \& Charters, 2007).

According to Galvão and Pereira (2014), for the elaboration of a systematic review it is necessary to accomplish the following steps: elaboration of the research/objective question, bibliographical survey, selection of the articles, data extraction, evaluation of the methodological quality; synthesis of data or meta-analysis, assessment of the quality of the evidences and writing and publication of results.

In the first step, the guiding question was defined, being: How have the development of public policies in Brazil in the last 10 years taken place? In the second step, the bibliographical survey was performed, using the Scientific Electronic Library Online database (SCIELO) and SCOPUS (bibliographic database) in the Periodicals Portal of the Coordenação de Aperfeiçoamento de Pessoal do Nivel Superior (CAPES) between the years of 2010 and 2019, the survey was carried out in April 2020.

In the third step, the articles were selected from the descriptor "Public Policies" using the bibliometric research technique in the chosen bases, characterized by the intentional choice, that were available, fit the research objective and the journal had qualifications equal to or greater than B1 according to an evaluation for the 2013-2016 
quadrennium available on the CAPES Sucupira platform (CAPES, 2020). In Figure 1, the selection of articles was illustrated.

Figure 1 - Articles selected in the SCIELO and SCOPUS databases between from 2010 to 2019:
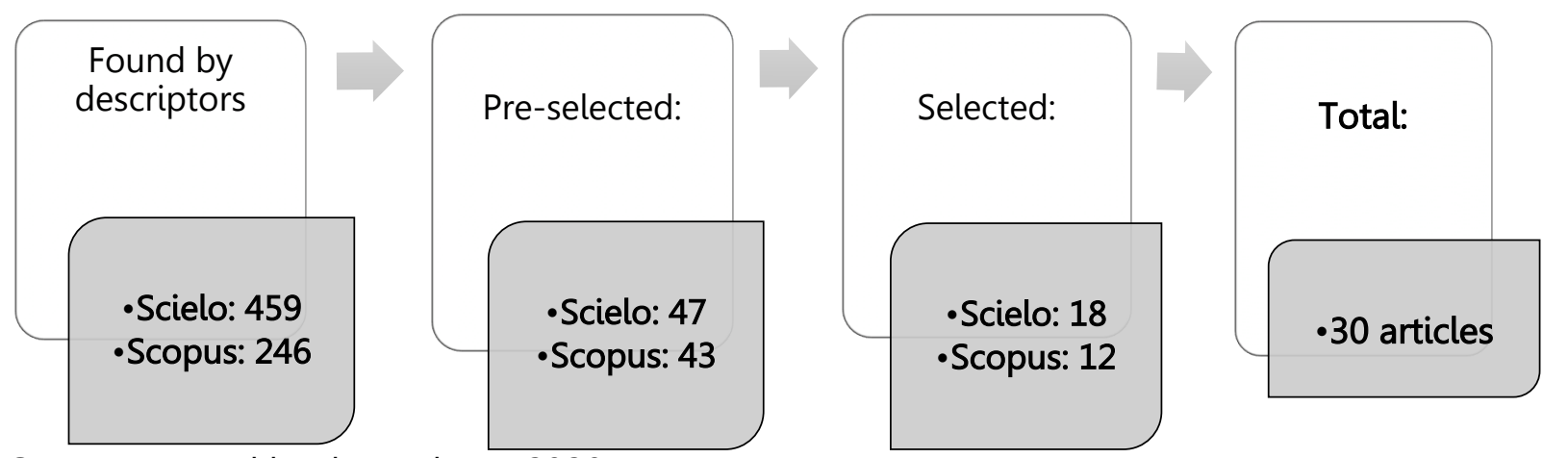

Source: created by the authors (2020).

In the next section, the results and discussion obtained after following the proposed methodology are going to be discussed.

\section{Results and discussion}

According to the proposed objective and the research methodology used, thirty relevant studies were identified and in accordance with the addressed issue. In order to assist in viewing the main results of the selected articles, the following information was cataloged in Chart 1: database, year of publication, title and methodology.

Chart 1 - Summary of selected articles:

\begin{tabular}{|c|c|c|c|}
\hline Database & Authors/ year & & Title \\
\hline \multirow{7}{*}{ SCIELO } & $\begin{array}{l}\text { Oliveira \& Passador } \\
\qquad(2019)\end{array}$ & 1 & Theoretical essay on public policy evaluations \\
\hline & $\begin{array}{l}\text { Almeida \& Gomes } \\
\qquad(2018)\end{array}$ & 2 & $\begin{array}{c}\text { The process of public policy: literature review, } \\
\text { theoretical reflections and suggestions for future } \\
\text { research }\end{array}$ \\
\hline & $\begin{array}{l}\text { Valle } \\
(2018)\end{array}$ & 3 & $\begin{array}{l}\text { Budget planning and public policies: exploring an } \\
\text { alternative of reconciliation by induction }\end{array}$ \\
\hline & Petinelli (2017) & 4 & $\begin{array}{c}\text { Who do public policy conferences serve? Institucional } \\
\text { design and stakeholders }\end{array}$ \\
\hline & $\begin{array}{l}\text { Santos, Ribeiro, } \\
\text { Ribeiro \& Pinto } \\
\quad(2017)\end{array}$ & 5 & $\begin{array}{l}\text { Political Administration and Public Policies: building a } \\
\text { new theoretical and methodological approach to } \\
\text { understand social relations of production, circulation } \\
\text { and distribution }\end{array}$ \\
\hline & $\begin{array}{l}\text { Batista \& Domingos } \\
\text { (2017) }\end{array}$ & 6 & $\begin{array}{c}\text { More than good intentions: quantitative and } \\
\text { qualitative technics in the impact evaluation of public } \\
\text { policies }\end{array}$ \\
\hline & $\begin{array}{l}\text { Chaebo \& Medeiros } \\
\text { (2017) }\end{array}$ & 7 & $\begin{array}{l}\text { Conceptual reflections on co-production of public } \\
\text { policies and directions for future research }\end{array}$ \\
\hline
\end{tabular}




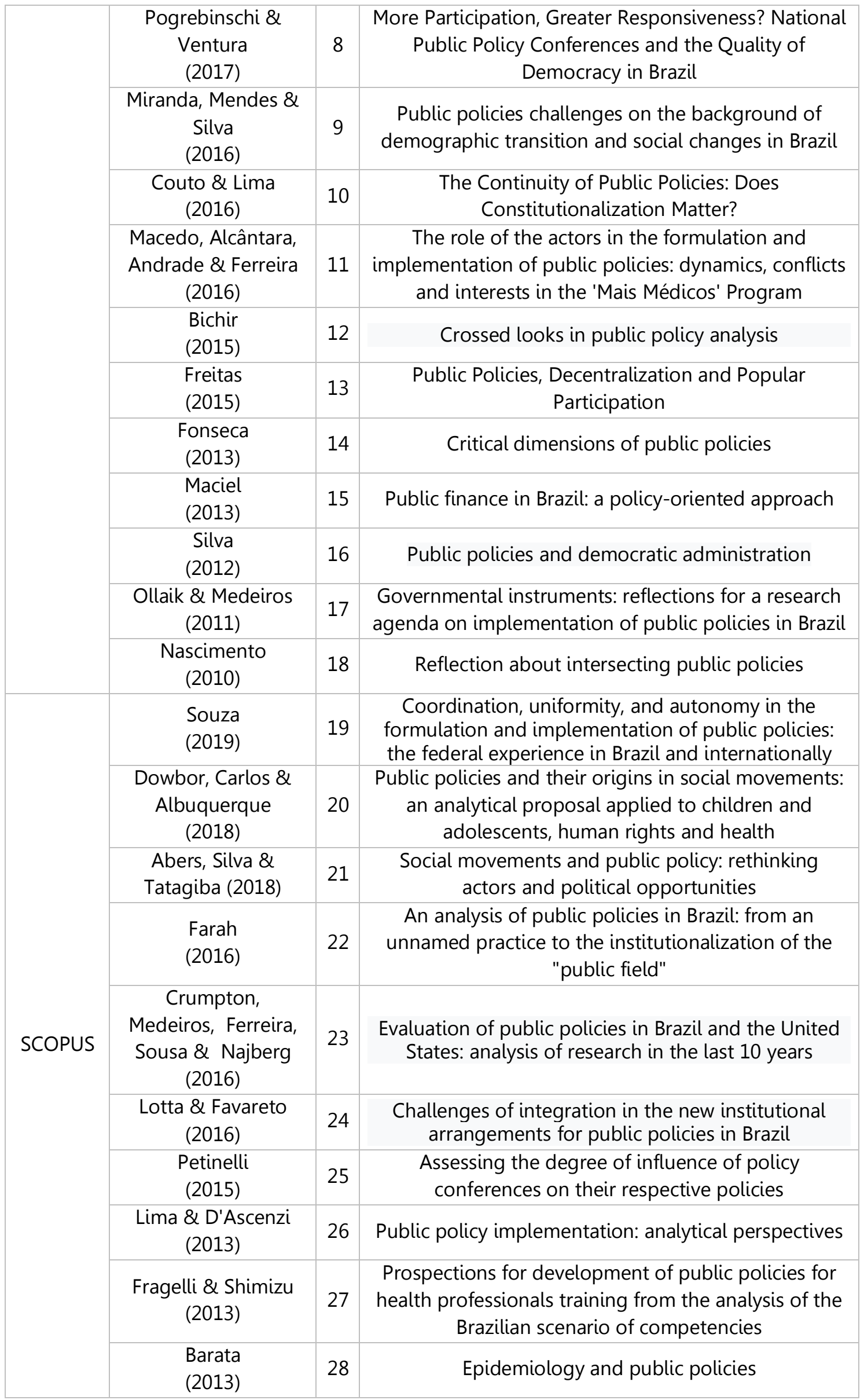


Ramos \& Schabbach

(2012)

Vaz

(2011)
29

30
The state of the art of public policy

evaluation: concepts and examples of evaluation in Brazil

Political participation, effects and results in public policies: critical-analytical notes

Source: created by the authors (2020).

Among the selected articles, it was noted that these are part of fifteen high impact scientific journals, being the majority number part of two Qualis CAPES A2 journals (2013-2016 Evaluation): Caderno da Escola Brasileira de Administração Pública e de Empresas da Fundação Getúlio Vargas (Cadernos EBAPE.BR) and Revista de Administração Pública (RAP).

Chart 2 - Qualis CAPES of the journals in which the selected articles were published:

\begin{tabular}{|c|c|c|}
\hline QUALIS & Journals & Quantity \\
\hline A2 & Cadernos EBAPE.BR & 6 \\
\hline A2 & Revista de Administração Pública & 5 \\
\hline B1 & Opinião Publica & 3 \\
\hline B1 & Lua Nova & 2 \\
\hline B1 & Revista Brasileira de Ciências Sociais & 2 \\
\hline B1 & Revista de Sociologia e Política & 2 \\
\hline A2 & Dados & 2 \\
\hline B1 & Interface (Botucatu) & 1 \\
\hline B1 & Physis: Revista de Saúde Coletiva & 1 \\
\hline B1 & Revista Brasileira de Epidemiologia & 1 \\
\hline B1 & Sequência (Florianópolis) & 1 \\
\hline B1 & Serviço Social \& Sociedade & 1 \\
\hline A2 & Caderno Saúde Pública & 1 \\
\hline A2 & Revista Katálysis & 1 \\
\hline A1 & Revista de Investigações Constitucionais & 1 \\
\hline
\end{tabular}

Source: Adapted from the sucupira platform website (Qualis periódicos) (2020).

The analysis made it possible to divide the articles into thematic axes, in order to better expose the results and discussion, namely: context of public policies in Brazil (10), actors and social movements (9) and public policies cycle (11). These were identified after descriptive and qualitative analysis of the bibliographic sample.

Chart 3 - Classification of selected articles:

\begin{tabular}{|c|c|}
\hline Thematic axes & Articles \\
\hline Context of public policies in Brazil & $2,3,5,9,14,15,16,18,22,24$ \\
\hline Actors and social movements & $4,8,11,13,20,21,25,27,30$ \\
\hline public policies cycle & $1,6,7,10,12,17,19,23,26,28,29$ \\
\hline
\end{tabular}


Source: created by the authors (2020).

The results and discussion follow divided into subtitles based on the thematic axes listed in Chart 3.

\section{Context of public policies in Brazil}

In this axis, it was sought to understand what makes up the context of public policies in the Brazilian territory, for this, ten articles were analyzed.

Policy analysis has taken place in Brazil since the 1930s. (Farah, 2016). The greatest number of scientific production comes from abroad, which implies the absence of particularities of the Brazilian reality, such as the tendency to analyze national public policies from the perspective of other realities unable to adapt to institutions, actors, political culture, among other factors that are typical in Brazil, which ends up neglecting some issues (Fonseca, 2013).

Another aspect that deserves to be highlighted concerns the demographic transition that the Brazilian population is going through, with the inversion of the age group pyramid, by means of the reduction of fertility, birth rates, infant mortality and the increase in life expectancy at birth, consequently it brought greater changes and social inequalities (Miranda, Mendes \& Silva, 2017).

These changes require adequate policies so that demography can contribute to economic and social development, of the well-being of society and care for the environment. It would be essential to implement public policies that respond to the needs generated by rapid demographic changes, such as health policies for a good quality of life and healthy aging and the reduction of inequities (Miranda et al., 2017).

An international comparison noted that Brazil spends excessively on pension funds ${ }^{1}$, even though the Brazilian demography is still young. This trend is expected to deteriorate in the medium term, which will require reforms in the retirement rules that converge to the international standard. In relation to Health, Labor and Defense, it was found that the amount of resources allocated to these sectors remains close to the international average (Maciel, 2013).

\footnotetext{
${ }^{1}$ The pension reform came about with the need to boost productivity in order to reduce or make possible the costs related to social security financing for future generations. In Brazil, the need to reform arises not only from the need to correct distortions but also from the need to guarantee fiscal sustainability in the medium and long term in a context of rapid and intense population aging. Therefore, it is observed that the country already faces high levels of expenditure and with a growing and unsustainable trajectory, as well as at a level much higher than what would be expected due to its current demographic structure, that is, even though it does not have such a high share of elderly in its population. These factors put pressure on the national tax burden and reduce the space for other sectors in the composition of public spending (Costanzi et al., 2018).
} 
Education was the sector in which the lowest allocation of resources in Brazil was observed in relation to the other countries, which is aggravated when considering the Brazilian demographic profile. Given the size of the Brazilian tax burden, it appears that there is ample scope for improving the quality of spending in all areas of the public sector (Maciel, 2013).

In this context, Lotta and Favareto (2016) highlight that in recent years the Brazilian federal government has experimented with a variety of institutional arrangements aiming to produce effective public policies in a national context, where it is possible to observe the presence of three prominent components, the articulation of intersectoral themes, the construction of policy management models with coordination between federal entities and civil society and the search for rooting in local contexts of policies implementation.

The intersectionality of public policies has become a dimension valued as the efficiency, effectiveness and efficacy expected in the implementation of sectoral policies were not observed, primarily concerning the meeting of the demands of the population and the resources made available for their execution. Bringing the articulation of technical knowledge, since the specialists in a given area started to integrate collective agendas and share common goals (Nascimento, 2010).

A major obstacle to the implementation of public policies in Brazil is the dissociation between budget planning and public policies, which can be seen in several news from executive authorities and control agents in relation to discontinuities in public actions, often caused by budgetary difficulties, absence or insufficiency of specific resources prevision, frustration or deviations in the execution of that same budget when the provision exists (Valle, 2018).

Public administration is essential in all stages of public policies so that public choices are shown to be efficient and are able to achieve the intended results, not only by the administration, but by the whole society, it is essential that the allocation of wills occur through the participation of its legitimate stakeholders, especially regarding the discussion and definition of the purposes that each policy is willing to serve (Silva, 2012).

The various ways of managing social organizations must integrate the political dimensions and also accept the technological dimensions, as a reflection, therefore, of the possibilities of materializing a given project in a society (Santos, Ribeiro, Ribeiro \& Pinto, 2017). For this, the analysis of the actors' capacity of influence in terms of both the resources possessed and the relationships established must be part of the composition of the research agenda (Almeida \& Gomes, 2018). 
The changes in the Brazilian scenario highlighted by these authors, presents the importance of the formulation, implementation and evaluation of public policies, this process demands the participation and formation of actors and social movements which will be highlighted in the next axis.

\section{Actors and social movements}

In this axis, nine articles that addressed the origin of social movements, participation in public policy conferences, how the actors collaborate with the formulation of public policies were approached.

For Dowbor, Carlos and Albuquerque (2018), social movements originate from three terms: social innovation, alternative and instrument. Social innovation refers to pilot projects that seek to solve social problems for which there are still no structured responses in public services or to which the government has never paid attention, for this to happen it is necessary that these innovations operate as alternatives, for this it needs to comprehend technical viability, congruence with the values of members of the community of experts in the field and budgetary limits, in addition to public acceptability and politicians' receptivity. Competing with alternatives, the movement's proposal may or may not be adopted by government officials and public managers as an instrument of public policy.

Social movements, as expedients of political action, were constituted, from the Federal Constitution of 1988, on the two main guiding axes of organization of public policies. With this evolution, the essentials took shape and the valorization of the democracy of local power was strengthened (Freitas, 2015).

Social and deliberative participation is already part of Brazilian democracy. Public policies conferences are part of these institutional spaces for debating and deciding on guidelines and priorities for a given policy.

These conferences were convened by the Executive Branch, often in partnership with civil society, enabling both sides to discuss and build guidelines together, that is, policy recommendations to be possibly adopted by the government in certain areas. These are organized around themes or policy areas and follow a staggered process that starts in the municipalities, goes to the federal states through the election of delegates and the approval of guidelines, and then ends with a national stage ( Pogrebinschi \& Ventura, 2017).

Public policy conferences have served as spaces for the inclusion of new voices in the policies discussion process. From these there have been emerging a set of proposals for the competent institutions, which express, to a lesser or greater extent, the 
demands and interests of the categories present in them. The influence capacity of each sector is constrained, however, by the institutional design of the meeting, which can favor or limit the participation and decision opportunities of societal actors throughout the process (Petinelli, 2017).

As potentially plural and democratic spaces, conferences can generate results, often little representative of this diversity, due to the representative and deliberative dynamics they establish. In political contexts less permeable to participation, the relationship between institutional design and the actors' capacity to influence becomes even more relevant, given the potential inclusive gains of the implementation of participatory arrangements in the midst of the public policies process (Petinelli, 2017).

Pogrebinschi and Ventura (2017) demonstrated how democratic innovations, by means of the participation of citizens and civil society actors, can make representative institutions more responsive and, thus, increase the quality of contemporary democracies. For that, a model of analysis of the concept of responsiveness was formulated from three levels: impact on public policies, thematic congruence and equality, and multidimensionality of representation.

At the national level, the expansion of social participation and the influence of societal actors in the decisions of political actors can be attributed, among other reasons, to the holding of conferences in a wide and varied set of sectoral policies. From the debates between state and non-state actors in these participatory arenas, thousands of recommendations have been produced and forwarded to the competent political institutions to be incorporated into the respective public policies (Petinelli, 2015).

According to Freitas (2015), the rules of popular participation must be formulated from a broad and democratic debate, because it should also start from the organized population itself, the definition of autonomous associative agendas and spaces such as consultative councils, popular consultations, forums, assemblies , conferences, congresses, organically articulated to class movements. Participation must be understood as a continuous process which seeks the democratization of government and public administration businesses.

The opportunities and constraints faced by social movements in the performance in public policies become framed as products of simultaneous and reciprocal agency of various actors, networks and institutions, including the movements themselves (Abers, Silva \& Tatagiba, 2018).

As for professionals, Macedo, Alcântara, Andrade and Ferreira (2016), Fragelli and Shimizu (2013) deal with the training of health professionals at the expense of public policies, considering the need for professionals prepared to deal with the new demands 
of the sector. On the path for the democratization of the country, public policies have a fundamental role and need to be analyzed as a multidisciplinary field and still open to various contributions, views and perspectives. It is believed that the main contribution was to move towards the realization that public policies are made up of networks of interests, conflicts, power relations, ideologies, dispute over resources and legitimacy.

According to Vaz (2011), in cities with greater propensity towards participatory, there is also a tendency to find better results along the considered frames. Especially in the managerial area, this factor is important, since this field predicts the capacity of the local government to design, implement, manage, administer, monitor and evaluate policies and results in its territory, contributing, mainly, for fiscal responsibility regarding expenses and the effective improvement of citizens' "quality of life".

The purpose of this axis was to demonstrate that public policies can originate from social movements in order to contribute to institutional changes and the importance that managers and workers exert in encouraging their participation, as policies are created for the "public" and therefore must be created with the "public". In the next axis, it will be analyzed the process of creating public policies, focusing on their evaluation.

\section{Public policies cycle}

In this axis, we will deal with some stages of the public policy cycle, also known as the public policy making process. Secchi et al. (2019), summarized this process in seven main phases, as shown in Figure 2:

Figure 2 - Synthesis of the public policy cycle phases:

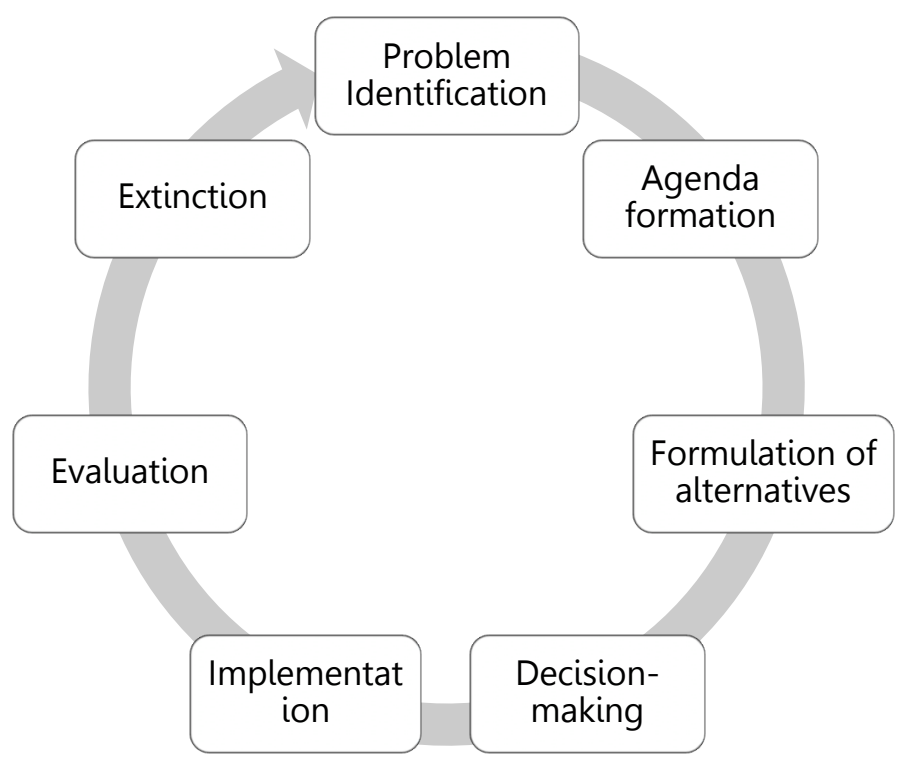


These phases actually appear in an overlapping and not sequential manner (Secchi et al., 2019). In many cases, as it can be seen below in the eleven articles selected for this axis. The most prominent phase of the cycle in the articles is the evaluation of public policies, due to the current indispensable demand for quality, efficiency and policy evaluation.

It can be said, preliminarily, that evaluation is an important instrument for improving the efficiency of public spending, the quality of management, social control over the effectiveness of State action, the latter being instrumentalized in the dissemination of results of government actions (Ramos \& Schabbach, 2012).

For the evaluation of public policies there are two approaches (quantitative and qualitative), however these evaluations are always limited when they are concentrated in only one of these approaches. It is important to have an accurate estimate of the impact, mainly to support decisions regarding the maintenance or extinction of government programs (Batista \& Domingos, 2017).

The practice of evaluation strengthens institutional arrangements and provides managers with an analysis of the adopted policies. In Brazil, the available public databases present problems of reliability, unavailable data and discontinuity in the production of indicators; such factors may contribute to the low adherence to quantitative evaluative studies (Oliveira \& Passador, 2019).

Thus, evaluations in Brazil would have a greater number of qualitative evaluations of a more local aspect and of specific policies analysis, mainly focused on accountability and performance measurement and in search of the quality of provided services. It is necessary to point out the importance of continuous evaluative actions, especially in scenarios of financial, human and material resources scarcity. Such evaluations can contribute to the appropriate allocation of resources and the strengthening of control actions by the responsible bodies (Oliveira \& Passador, 2019).

However, there is a growing interest of Brazilian government officials in the evaluation, being related to issues of effectiveness, efficacy, efficiency, performance and accountability of public management. Evaluation allows the government a certain knowledge of the results of a given program or project, information that can be used to improve the design or implementation of public actions, to base decisions, to promote accountability (Ramos \& Schabbach, 2012).

According to Bichir (2015), in Brazil, especially after redemocratization, public policy production processes are increasingly complex. They involve thematic diversity, a large number of state and non-state actors in intricate patterns of interaction and 
decision-making processes that take place in different arenas, with consequences for different audiences. Building analytical models to understand the production of public policies, from decision-making to implementation and evaluation, is not a trivial task. This implies, at the analytical level, explanatory models that combine different disciplinary contributions through the coherent articulation of various theoretical and methodological arsenals, in addition to macro explanations that are sometimes superficial.

Regarding scientific research on public policy evaluation, a study comparing Brazil and the United States, it is allowed from the results found to affirm the proposition that research in evaluation is not yet fully established as a research area in Brazil, as it is in the United States. Despite this, these results offer evidence of advances in evaluation research in Brazil (Crumpton, Medeiros, Ferreira, Sousa \& Najberg, 2016).

Another interesting piece of evidence is that, in both countries, institutional partnerships of researchers for policy analysis and evaluation are not restricted to universities. They maintain partnerships with public organizations that provide services to citizens, such as local governments and health departments of the federal government and local governments, which suggests, therefore, that these organizations are taking an active role in current scientific research regarding the evaluation of policies (Crumpton et al., 2016).

The impacts of public policies on the federation brought several innovations, such as the recognition of social rights, the universalization of access to health care, an increase in competing competences between the three levels of government. This created the basis for the current design of public policies, notably social policies, with federal regulation and almost always local implementation. These innovations were responsible for the Union's ability to circumvent the federal dilemmas, to achieve the adhesion of the other spheres to the implementation and financing of national policies, also stimulated by incentives for their adhesion, and by the approval of constitutional amendments that put into practice some social rights (Souza, 2019).

Ramos and Schabbach (2012) cite the difficulties of carrying out the evaluation of public policies: many programs and actions are not designed to be evaluated; the prevalence of research designs that do not "control" the antecedent, procedural and outcome variables, and that produce spurious inferences, attributing to the program the responsibility for results (good or bad) not caused by it, but by other factors; few data available and, when available, very limited and with irregular frequency; resistance in public administration, due to the predominance of an authoritarian culture. 
There is the embarrassment of public authorities in relation to their actions being analyzed and they react through: direct prohibitions, or placing bureaucratic difficulties: lack of interest in data collection, making sources inaccessible, lack of support (Ramos $\&$ Schabbach, 2012).

The formulation phase consists of the processes for defining and choosing the problems that deserve state intervention, producing solutions or alternatives and making decisions. The implementation refers to the execution of the decisions adopted in the previous stage. The evaluation consists of questioning the impact of the policy (Lima \& D'Ascenzi, 2013).

Lima and D'Ascenzi (2013), identified two main models of public policy implementation, these models emphasize the material conditions of the development of the implementation process. The models presented differ in terms of the focus of analysis. The first focuses on the characteristics of the normative framework, the second on the implementing actors and their actions. In common, the approaches emphasize material conditions and limitations, seen as being determinant for the trajectory of the implementation process. Such emphasis leaves space for the insertion of variables linked to the actors' ideas, values and worldviews.

Considering that the implementation occurs using government instruments, these instruments partially determine which resources will be used and by whom. Like any other institution, the instruments allow forms of collective action to stabilize and make the actors' behavior more predictable and probably also more visible. The study of these is of fundamental importance for solving problems and improving the process of implementing public policies (Ollaik \& Medeiros, 2011).

Regarding the continuity of public policies, it can be affected by several relevant factors, such as a coalition of stakeholders, coordination problems and stakeholder investments, when present and at different intensities. Constitutionalization is also a factor and it matters for the continuity of policies when it has mechanisms that protect it: citizens are mobilized in their defense, the rules of amendment are difficult, and the judiciary is independent and empowered to exercise control over constitutionality (Couto \& Lima, 2016).

On the other hand, the constitution is relevant when the policy has no sources of resilience on its own: there are few and/or weak actors interested in its preservation, coordination problems in favor of an alternative can be easily overcome, and the policy did not create a feedback process. If public policy has or develops such support mechanisms, the importance of constitutionalization for its continuity decreases (Couto \& Lima, 2016). 
In summary in public health policies, epidemiology contributes to all stages of the public policy cycle. In the stage of identifying socially relevant problems through the study of the distribution of health problems and their determinants in different social groups, providing technical information to support political decisions. In the formulation of policies stage, in the mechanisms of health problems production and on the effectiveness or efficiency of the intervention instruments. In the implementation stage, epidemiology can contribute to monitoring through technologies such as epidemiological surveillance and monitoring. And in the evaluation process it is useful mainly in the analysis of the expected and achieved impacts (Barata, 2013).

Considering what was exposed and based on the research by Chaebo and Medeiros (2017), some research proposals were raised, such as: relating economic viability and democratic aspects, that is, whether the influence of citizens in public policy directions increases or decreases the efficiency of the co-production relationship; another would be to relate institutional arrangements, technical capacity and economic viability as legal, technical and economic factors that affect the dynamics of implementation.

In the next section, the final considerations of the work will be presented.

\section{Final considerations}

From the analysis of these articles, it was possible to understand aspects of the development of Brazilian public policies, their involvement with the actors and the phases of the public policy cycle.

The analysis of public policies in Brazil can be considered recent, but with great advances that came from the Federal Constitution of 1988. Each country has its particularities, in Brazil it is possible to see that the population is undergoing a change in the demographic pyramid, what directly affects the changes and adaptations of public policies.

An obstacle is the picture of these changes and the perceived dissociation between budget planning and public policies, which hinders the continuity of actions, as much as a policy has been formulated with high quality, without adequate resources it does not achieve its purpose, showing that public administration is essential from the formulation to the continuity or extinction of a policy.

The changes in the Brazilian scenario, demonstrate the importance of the formulation, implementation and evaluation of public policies, this process demands the participation and formation of actors and social movements. Social and deliberative participation is already part of Brazilian democracy, at least by law. These participations 
have the power to make representative institutions more responsive and, thus, expand the quality of contemporary democracies.

As for the public policy cycle, evaluation was highlighted as an important instrument for improving the efficiency of public spending, the quality of management, and social control over the effectiveness of State action. However, there are difficulties in carrying out these assessments, such as the form that was designed, without realizing the importance of the evaluation.

As for the continuity of public policies, it was noted that they can be affected mainly by the dissociation with budget planning, political interests, coordination and social monitoring.

It is concluded that in Brazil the evolution of public policies is directly linked to the Federal Constitution, to guarantee citizens' rights, which can directly contribute to the creation of policies that meet their needs and their continuity.

It is suggested for further research practical evaluations of public policies that use quantitative and qualitative methods together, considering the design of this evaluation so that the execution is viable. As well as the realization of studies, which can verify the new dimensions of analysis and can contribute to increase the understanding about the results and the evolution of public policies.

\section{References}

ABERS, Rebecca Neaera; SILVA, Marcelo Kunrath; TATAGIBA, Luciana. Movimentos sociais e políticas públicas: repensando atores e oportunidades políticas. Lua Nova, São Paulo, n. 105, p. 15-46, set. 2018.

ALMEIDA, Lia de Azevedo; GOMES, Ricardo Corrêa. Processo das políticas públicas: revisão de literatura, reflexões teóricas e apontamentos para futuras pesquisas. Cad. EBAPE.BR, Rio de Janeiro, v. 16, n. 3, p. 444-455, Set. 2018.

BARATA, Rita Barradas. Epidemiologia e políticas públicas. Rev. bras. epidemiol. São Paulo, v. 16, n. 1, p. 3-17, março de 2013.

BATISTA, Mariana; DOMINGOS, Amanda. Mais que boas intenções: técnicas quantitativas e qualitativas na avaliação de impacto de políticas públicas. Rev. bras. Ci. Soc., São Paulo, v. 32, n. 94, e329414, 2017.

BICHIR, Renata. Olhares cruzados nas análises de políticas públicas. Rev. bras. Ci. Soc., São Paulo, v. 30, n. 89, p. 175-181, Oct. 2015.

BORK, Anna Margherita Toldi. Enfermagem Baseada em evidências. Rio de Janeiro: Guanabara Koogan; 2005. 
BRASIL. Ministério da Saúde. Secretaria de Ciência, Tecnologia e Insumos Estratégicos. Diretrizes metodológicas: elaboração de revisão sistemática e metanálise de ensaios clínicos randomizados. Brasília: Editora do Ministério da Saúde, 2012.

CAPES. Plataforma Sucupira. Qualis Periodicos. Classificassão de quadriênio 2013-2016, 2020.

CHAEBO, Gemael; MEDEIROS, Janann Joslin. Reflexões conceituais em coprodução de políticas públicas e apontamentos para uma agenda de pesquisa. Cad. EBAPE.BR, Rio de Janeiro, v. 15, n. 3, p. 615-628, July 2017.

COSTANZI, Rogério Nagamine; AMARAL, Aline Diniz; DIAS, Cicero Rafael; ANSILIERO, Graziela; AFONSO, Luis Eduardo; SIDONE, Otávio José Guerci. reforma da previdência social. In: IPEA - Instituto de Pesquisa Econômica Aplicada. Desafios da Nação, 2018, cap. 20.

COUTO, Cláudio Gonçalves; LIMA, Giovanna de Moura Rocha. Continuidade de Políticas Públicas: A Constitucionalização Importa?. Dados, Rio de Janeiro, v. 59, n. 4, p. 1055-1089, Out. 2016.

CRUMPTON, Charles David et al. Avaliação de políticas públicas no Brasil e nos Estados Unidos: análise da pesquisa nos últimos 10 anos. Rev. Adm. Pública, Rio de Janeiro, v. 50, n. 6, p. 981-1001, Dec. 2016.

DOWBOR, Monika; CARLOS, Euzeneia; ALBUQUERQUE, Maria do Carmo. As origens movimentistas de políticas públicas: proposta analítica aplicada às áreas de criança e adolescente, direitos humanos e saúde. Lua Nova, São Paulo , n. 105, p. 47-80, Sept. 2018.

FARAH, Marta Ferreira Santos. Análise de políticas públicas no Brasil: de uma prática não nomeada à institucionalização do "campo de públicas". Rev. Adm. Pública, vol.50, n.6, 2016.

FONSECA, Francisco. Dimensões críticas das políticas públicas. Cad.EBAPE.BR, Rio de Janeiro, v. 11, n. 3, 2013.

FRAGELLI, Thaís Branquinho Oliveira; SHIMIZU, Helena Eri. Prospecções para desenvolvimento de políticas públicas de formação de profissionais de saúde a partir da análise do cenário brasileiro de competências. Physis, Rio de Janeiro, v. 23, n. 1, p. 197-208, 2013.

FREITAS, Leana Oliveira. Políticas públicas, descentralização e participação popular. Rev. katálysis, Florianópolis, v. 18, n. 1, p. 113-122, June 2015.

GALVAO, Taís Freire; PEREIRA, Mauricio Gomes. Revisões sistemáticas da literatura: passos para sua elaboração. Epidemiol. Serv. Saúde, Brasília, v. 23, n. 1, p. 183184, mar. 2014. 
KITCHENHAM, Barbara; CHARTERS, Stuart. Guidelines for performing systematic literature reviews in software engineering. Technical Report EBSE 2007-001, Keele University and Durham University Joint Report, 2007.

LIMA, Luciana Leite; D'ASCENZI, Luciano. Implementação de políticas públicas: perspectivas analíticas. Rev. Sociol. Polit. Curitiba, v. 21, n. 48, 2013.

LOTTA, Gabriela; FAVARETO, Arilson. Desafios da integração nos novos arranjos institucionais de políticas públicas no Brasil. Rev. Sociol. Polit., Curitiba, v. 24, n. 57, p. 49-65, mar. 2016.

MACEDO, Alex dos Santos et al. O papel dos atores na formulação e implementação de políticas públicas: dinâmicas, conflitos e interesses no Programa Mais Médicos. Cad. EBAPE.BR, Rio de Janeiro, v. 14, n. spe, p. 593-618, 2016.

MACIEL, Pedro Jucá. Finanças públicas no Brasil: uma abordagem orientada para políticas públicas. Rev. Adm. Pública, Rio de Janeiro, v. 47, n. 5, p. 1213-1241, Oct. 2013.

MIRANDA, Gabriella Morais Duarte; MENDES, Antonio da Cruz Gouveia; SILVA, Ana Lucia Andrade da. Desafios das políticas públicas no cenário de transição demográfica e mudanças sociais no Brasil. Interface, Botucatu, v. 21, n. 61, p. 309-320, June 2017.

NASCIMENTO, Sueli do. Reflexões sobre uma intersetorialidade entre as políticas públicas. Serv. Soc. Soc. São Paulo, n. 101, p. 95-120, 2010.

OLIVEIRA, Lilian Ribeiro de; PASSADOR, Claudia Souza. Ensaio teórico sobre as avaliações de políticas públicas. Cad. EBAPE.BR, Rio de Janeiro, v. 17, n. 2, p. 324337, 2019.

OLLAIK, Leila Giandoni; MEDEIROS, Janann Joslin. Instrumentos governamentais: reflexões para uma agenda de pesquisas sobre implementação de políticas públicas no Brasil. Rev. Adm. Pública, Rio de Janeiro, v. 45, n. 6, p. 1943-1967, 2011.

PETINELLI, Viviane. Aferindo a capacidade de influência das conferências de políticas públicas sobre os programas das respectivas políticas setoriais. Opin. Publica, Campinas, v. 21, n. 3, p. 643-672, 2015.

PETINELLI, Viviane. A quem serve como reuniões de políticas públicas? Desenho institucional e atores beneficiados. Opin. Publica, Campinas, v. 23, n. 3, p. 612-646, 2017.

POGREBINSCHI, Thamy; VENTURA, Tiago. Mais Participação, Maior Responsividade? As Conferências Nacionais de Políticas Públicas e a Qualidade da Democracia no Brasil. Dados, Rio de Janeiro, v. 60, n. 1, p. 7-43, Mar. 2017. 
RAMOS, Marília Patta; SCHABBACH, Letícia Maria. O estado da arte da avaliação de políticas públicas: conceituação e exemplos de avaliação no Brasil. Rev. Adm. Pública, Rio de Janeiro, v. 46, n. 5, p. 1271-1294, Oct. 2012.

SANTOS, Reginaldo Souza et al. Administração política e políticas públicas: em busca de uma nova abordagem teórico-metodológica para a (re)interpretação das relações sociais de produção, circulação e distribuição. Cad. EBAPE.BR, Rio de Janeiro, v. 15, n. 4, p. 939-959, 2017.

SECCHI, Leonardo; COELHO, Fernando de Souza; PIRES, Valdemir. Políticas públicas: conceitos, categorias de análise, casos práticos. 3. ed. São Paulo: Cengage Learning, 2019.

SILVA, Rogério Luiz Nery da. Políticas públicas e administração democrática. Sequência, Florianópolis, n. 64, p. 57-85, 2012.

SMITH, Kevin B.; LARIMER, Christopher W. The Public Policy Theory Primer. Boulder- CO, Westview Press. 2009.

SOUZA, Celina Maria de. Coordenação, uniformidade e autonomia na formulação de políticas públicas: experiências federativas no cenário internacional e nacional. Cad. Saúde Pública, Rio de Janeiro, v. 35, supl. 2, 2019.

VALLE, Vanice Lírio do. Planejamento orçamentário e políticas públicas: explorando uma alternativa de reconciliação pela indução. Rev. Investig. Const., Curitiba, v. 5, n. 2, p. 113-134, Aug. 2018.

VAZ, Alexander Cambraia N. Participação política, efeitos e resultados em políticas públicas: notas crítico-analíticas. Opin. Publica, Campinas, v. 17, n. 1, p. 163-205, June 2011. 


\section{Crevisto Observatório}

\section{RESUMO:}

Este estudo teve como objetivo analisar a evolução das políticas públicas no Brasil no período de 2010 a 2019, sob a ótica do seu desenvolvimento, o envolvimento dos atores e movimentos sociais e o desenvolvimento das fases do ciclo de políticas públicas. Foram identificados trinta estudos relevantes e em conformidade com a problemática abordada. A análise possibilitou a divisão dos artigos em eixos temáticos, a fim de uma melhor exposição dos resultados e discussão, sendo eles: contexto das políticas públicas no Brasil, atores e movimentos sociais e ciclo de políticas públicas. Pode-se considerar recente a análise de políticas públicas no Brasil, porém com grandes avanços que sobrevieram a partir da Constituição Federal.

PALAVRAS-CHAVE: Gestão Pública. Políticas Públicas. Ciclo de Políticas Públicas.
e-ISSN n ${ }^{\circ} 2447-4266$

Palmas, v. 7, n. 1, p. 1-19, jan.-mar., 2021

http://dx.doi.org/10.20873/uft.2447-4266.2021v7n1a14en

\section{RESUMEN:}

Este estudio tuvo como objetivo analizar la evolución de las políticas públicas en Brasil de 2010 a 2019, desde la perspectiva de su desarrollo, la participación de los actores y movimientos sociales y el desarrollo de las fases del ciclo de políticas públicas. Se identificaron treinta estudios relevantes y de acuerdo con el problema abordado. El análisis permitió dividir los artículos en ejes temáticos, para exponer mejor los resultados y la discusión, a saber: el contexto de las políticas públicas en Brasil, los actores y los movimientos sociales y el ciclo de las políticas públicas. El análisis de las políticas públicas en Brasil puede considerarse reciente, pero con los grandes avances que provienen de la Constitución Federal.

PALABRAS-CLAVES: Gestión Pública. Políticas públicas. Ciclo de Políticas Públicas. 